\title{
The Interplay of Religious Symbols and Cultural Values Theory in Advertising
}

\begin{abstract}
The purpose of this paper is to analyse symbolic advertising and its effect on cultural values in the consumer society. A conceptual framework is grounded in the scientific literature analysis on Christian religious symbols in advertising along with a critical view of its impact on consumers' cultural values. There is a lack of empirical studies regarding consumers' approaches towards religious symbols in advertising and their impact on consumption in different cultural values. In this article we are trying to seek an alternative approach to advertising, social, and cultural trends in society.
\end{abstract}

Keywords: religious symbols, consumerism, advertising, branding, cultural values.

Straipsnio tikslas - išanalizuoti simbolinę reklamą, jos poveikị kultūros vertybėms, prekès ženklo sekejjams vartotojiškoje visuomenèje ir patikrinti teorijų pritaikomumą praktiškai, atlikti šios problematikos mokslinès literatūros analizę. Pastaruoju metu pasigendama tyrimų apie vartotojų požiūrị ị religinių simbolių reklamoje naudojimą ir jų poveikị vartojimui skirtingose kultūrose, todẻl bandoma pateikti alternatyvų požiūrị $\mathfrak{i}$ reklamą, socialines ir kultūrines visuomenès tendencijas.

Raktiniai žodžiai: religiniai simboliai, konsumerizmas, reklama, prekės ženklas, kultūros vertybès.

\section{Introduction}

Advertising is a part of our culture where consumers create their identities with the help of symbols hidden in the goods. Culture is the mutual programming of people's thinking that appears not only in values but also in more superficial ways such as in symbols, heroes, and rituals. In this article we state that symbols in culture (and its values) can take different forms, such as logos, celebrities (influencers), slogans, and even social stereotypes (Hofstede, Minkov, 2010).
Humans have always sought fulfillment, and it is obvious that pure materialism cannot bring happiness since a combination of the spiritual and material is what fulfils our lives. Advertising billboards claim that you can get friendship, family life, or status through specific things. The process of purchasing could be used as a medium between goods and the real reason one needs that thing or service. This necessity can even rise to spiritual level. Normally and most often, this spiritual buying process happens through symbolic language or by symbols

Rima ŽITKIENE - professor at the Faculty of Economics and Business, Mykolas Romeris University, Lithuania. Address: Ateities str. 20, Vilnius, LT-08303, Lithuania. Phone: +370 52 714651. E-mail: rizit3@mruni.eu Gintare KRIAUČIŪNAITĖ-LAZAUSKIENĖ - PhD student at the Faculty of Economics and Business, Mykolas Romeris University, Lithuania. Address: Ateities str. 20, Vilnius, LT-08303, Lithuania. Phone: +370 52714651 . E-mail: g.kriauciunaite@mruni.eu. 
themselves, which we instinctively have known since we started to recognize social language and our environment.

Despite negative aspects (brands becoming icons, making a fetish out of advertising, abusing religious images, or changing cultural values), symbolic advertising also brings positive ideas which advertising can put together just by representing brands and not seducing buyers by informing clients (e.g., organic products, genetically modified food, fair trade products) or by creating healthy attitudes and habits such as second-hand reuse, recycled, eco-friendly, or a local market product purchase. In this article, we are going to review on a more problematic part of this marketing phenomenon - the use of religious (Christian) symbols as a marketing strategy and imposed cultural values.

It is necessary to grasp the features of religious and spiritual expressions of managing and organizing in order to achieve a broader understanding about religious, spiritual and as everyday marketplace, and consumption habits. Furthermore, marketing and consumption research can illuminate on a less-understood phenomenon which is predominant in secularized societies since today's consumers combine values and different ideas as well as philosophies from different religious and spiritual traditions. Furthermore, the internet, social media, tourism, and immigration provide access to spiritual and religious resources and societies at a unique scale in this present global world.

This article builds upon a limited but growing literature in spirituality and symbolic meaning in advertising, which explores four main parts. First, we look at cultural dimensions and will try to elaborate on consumer culture and society as such by making comparisons with R. Inglehart (2000) and cultural dimensions. The second part reveals the meaning of religion and religious (Christian) symbols in advertising, emphasising the powerful meaning of them in culture together with the opinions of other researcher on this theme. The third part elaborates on branding and fetishism, revealing the meaning of brands and how they become a part of our consumer culture. The last part looks at the idea of the brand as a religion itself, having a secular meaning in consumers' lives and how specific companies use this idea in advertising.

The research object of this article will focus on exploring the link between religious symbols and advertising messages in culture which are bound together by examining the meaning of individuals driven from spiritually commercials adjusted by using the cultural value method developed by R. Inglehart (2000).

The aim of this paper is to conceptualise, analyse, discuss and evaluate emergent symbolic advertising and its effect to cultural values in consumer society.

The research method is a conceptual framework grounded in a scientific literature analysis on Christian religious symbols in advertising along with a critical view and impact on consumers' cultural values.

The objectives of the article are defined as the question: Why does advertising with symbols, attract people so much that it became a part of our cultural values? In short, the scientific problem could be stated as the relationship among religious (Christian) symbols and the messages in advertising as well as the outcomes from the purchasing part. We must take into account that brands are 
not just the products (or services) or even just ordinary labels. They are much more. The perfect example is of a box of chocolates: you want to give it to the person you like. A lot more is hidden in this chocolate. You are selecting the specific brand, and you want to demonstrate your attention (and if it is for a beloved, you want to emphasize your relationship with that person). Currently, marketing modifies its attention point from quality to emotional or transcendental experience (Klaus, Maklan, 2013; Dodson, 1996; Belk, 1995), and it becomes the main aspect for successful brand building.

\section{The rise of consumer culture}

After the Second World War, such terms as "consumer culture" (in some literature, consumer culture theory - CCT) or just "consumer society" became famous by such authors as J. Baudrillard (2001), H. Campbell and C. A. La Pastina (2010), R. W. Belk (1995), M. Featherstone (1991), D. Miller (1987), D. Slater (1997), and R. Inglehart et al. (2000). CCT posits that, in a modern world, essential personalities are explained and concerned with a connection to consumption (Holt, 2002). Though, in this content, consumer culture has been called "a 3.culture of consumption" (Slater, 1997 p. 8). Consumer culture illuminates the development of consumer's choice and seller's implications to the produced goods and services by building individual also collective identities (Kozinets, 2001; Holt, 2002). The global market offers consumers plenty of cultural and allegorical resources to endorse and identify a cultural scenario that brings into line personalities with the basic essentials of a consumer ambitious global economy.

The approach to this culture states that capitalism has transformed the world into a society of consumers with the constant need of purchasing things. Usually, this term does not offer a decent understanding of what is going on in society, but this meaning rather stigmatizes the growing and uncontrolled passion for goods. According to J. B. Twichell, the word "consume" sounds scary. It means to "ingest, use up totally" (Twitchell, 1999). J. Baudrillard (2001) states that consumer society via consumption became a new tribal myth which became the morality of today. As for more, it destroys the essence of humanity and the stability we created since the Greeks and their mythological foundation of the logos. Consumers associate consumption with innovation, progress, achievement, competence, and an assurance of abundance (Holton, 2000). This tactical appeal from producers to create similar tastes and needs by establishing global consumer segments such as for the wealth or for the youths (Hofstede et al., 2010).

To another extent, culture gives us language, narratives, categories, and other organizational schemes by which we make sense of ourselves and everything we deal with. Scholars from various disciplines have tried to describe culture (Hofstede, 1991; Hofstede, 2001; McSweeney 2002; Triandis, 2018). Academics have detailed the idea that culture is shaped from people's mutual environmental contexts (Hofstede, Minkov, 2010), life understanding (Heine, 2008), and basic need to live (Keith 2011). Essentially, culture survives for pursing a happy and significant life. It is almost impossible to find a consensus regarding this 
definition; therefore, culture is a part of an individual's link to physical and psychological well-being.

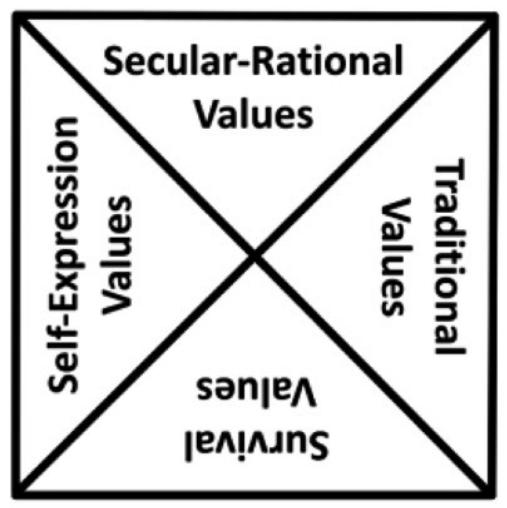

Fig 1. The cultural dimensions and their factor items

Source: R. Inglehart and C. Welzel (2015).

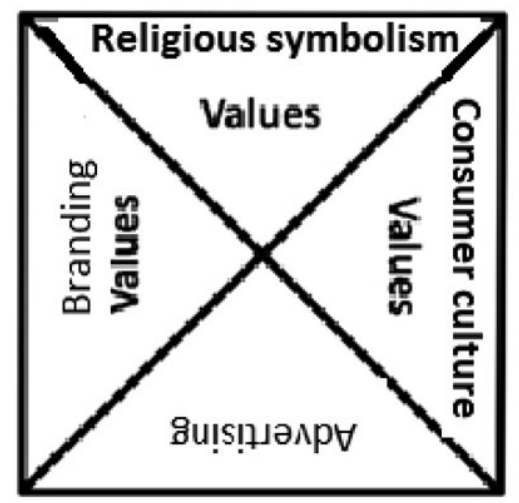

Fig. 2. Values in present research in comparison to Inglehart \& Welzel's values

Source: adjusted by the author G. Kriaučiūnaite-Lazauskienè.

For many years cultural studies have been analysed through the World Values Survey. This survey helps measure the unstable notion of value, which is defined in four parts: Survival, Traditional, SelfExpression and Secular-Rational. These social values are measured and compared in countries around the world, resulting in the Inglehart-Welzel Cultural Map.

Social and individual values are measured and divided in few sets of values that are autonomous, and for each of these values, the two types are dependent on contrariwise proportional to other type:

Survival values $\Leftrightarrow$ high; Self-expression values $\Leftrightarrow$ low (depends from one another);

Secular-rational values $\Leftrightarrow$ higher and Traditional values $\Leftrightarrow$ lower. Since this survey is mostly used for comparing countries, we tend to compare values as cultural acceptance for a person towards religious advertising and its acceptance in consumer culture (as general culture in the western part of the world). ${ }^{1}$

Consumerism, according to P. Ekins (1991), is a cultural model where "the possession and use of an increasing number and variety of goods and services is the principal cultural aspiration and the surest perceived route to personal happiness, social status, and national success" Ekins (1991, p. 247). Paraphrasing, it is a progressively mutual pattern among different cultures in order to find happiness and meaning as well as recognition via the goods we buy. Researchers, using several different strategies, including the WVS by R. Inglehart and C. Wezel (2005) claim that more goods may bring less happiness as well as more poor countries are more happy than rich (Inglehart, Wezel, 2005). This phenomenon is marked by spiritual pauperization, in which human beings are

\footnotetext{
1 In order to understand the importance of these values, you need to put in a pairs of numbers from 0 to 1 , which specifies how person and society comprehends among each other if survival values assumed as high measures and self-expression values as low (or zero), so if survival values are low, self-expression values are high. Likewise, secular-rational values are higher if traditional values are lower.
} 
persuaded, for convenience sake, to desire material goods, a surrogate for traditional forms of pleasure, self-realization and identification through work and political participation. In the second picture, we reestablished our own perception through the lenses of consumers' cultural value made by influence of advertising, attached to branding values creates religious symbolism values.

A huge impact for consumerism is established through celebrities (influencers), movie stars created by the media, even computer game heroes, with perfect bodies, things or different kinds of entertainment trying to seduce us and to present life as having more goods (even perfect) things as a goal of life (even the development of the child we defining by the heroes one likes at specific age "Batman age" or "Elza from Frozen age"). It has become important not because of natural survival but more for psychological comfort; happiness, popularity - just a part of the aims of consumer society. Buyers gather sensations not just to feel good. The main idea of goods is to possess things for pleasure. J. B. Twitchell (1999) argues that we satisfy our desires in shops, and not our needs, and we are doing it just in that order of satisfaction (Twitchell, 1999).

It is generally agreed that if advertising did not exist, people would not have "false needs" and of course, marketers would not try to content these needs in fake ways by buying countless possessions. As W. S. Leiss et al. (1990) notes, a lot of human satisfaction takes place in non-material domain, where objects are not essential. Unfortunately, in the author's understanding, the magic in advertising averts by suggesting all our needs will met in the object-laden traditions in the consumer marketplace (Leiss,
Kline, Jhally, 1990). The classical implication which expresses false needs is Nestlé baby formula which was sent to Kenya in order to adapt to modernity (to make life easier) and replace breast feeding. Unfortunately, the effect was tragic because the formula of the powder required sanitary conditions that were not possible in that country and a lot of babies became sick and even died. It shows that in such a cultural context, false needs cause much adversity rather than making life easier and creating a better place to live (Tiwari, Rajendra, 2012). We may raise the question: Are we not fulfilling our natural needs in a proper way and we are searching for superficial substitutions? According to J. Baudrillard (2001): "Consumers do not consume specific objects because of concrete and specific needs, but signs which are part of an abstract system that replace a contingent world of needs and pleasures with a special order of values and classifications. Tools and buildings are enduring. But today, we see the production, improvement and wither of ourselves" (Baudrillard, 2001, p. 112). Marketers seek to create visual needs, and consumers get this satisfaction via symbols in brands or advertising. Consumer society is the culture limited by objects and is built from mass consumption of commodities. These models not only make adjustments in purchasers' daily necessities but change their fundamental approaches to the world and themselves.

A certain relationship exists concerning the consumption objects in consumer culture, the promoter who manufactures, confirms, and manages such items, and the social groups who use these items as well. These relationships assist in filling the product with symbolic connotation within a specific cultural background. Consumers 
demonstrate specific tactics towards purchases and their advertisements built upon these cultural relationships. Contradictory observations of symbolic relationships with commodities and the symbols may have substantial impact on buying choices, too. Hence, relating a commodity with an essential cultural symbol, like the cross, is mostly to affect consumer behaviour concerning the product.

Marketing, and the system of economics in general, works almost perfectly because nothing can be obtained outside of it. To clarify more precisely, consumers are emotional beings and how one thinks, acts, or feels has a marvellous influence on the way we consume and are persuaded by advertising. Although, so far, advertisers and companies have not been able to control buyers by the variable powers that control our needs: trust, happiness, and of course, the way we spend our money, but we believe culture can make influence. A great amount of research on consumerism as an effect of advertising has put attention on cultural symbolism. The idea that products represent many things to consumers and their vital uses is well-known. Therefore, most advertisements use the circumstances in which these symbolic goods act in the marketplace via social environmental and buying process. Personal attachment to objective reality is connected by the symbolic meaning of such commodities (Solomon, 1992).

\section{The role of Christian religious symbols in advertising}

Advertising plays (games) with our emotions, feelings, belief-systems and symbols. In order to understand how it in- fluences us and marketing as such, we need to ascertain what place symbolism has in religion and more precisely in Christianity.

It is known, that one first historical hints of symbolic consumption has been found in the literature of $\mathrm{W}$. James (1890); J. C. Flügel (1930) and G. Simmel (1903) writings. These authors stated that people emphasise their identities thru the goods they buy. Nevertheless, the research of this perception as variable in the marketing field did not find in the literature until S. J. Levy (1959). This author highlighted that companies do not only sell pure products but "managers must attend to more than the relatively superficial facts with which they usually concern themselves when they do not think of their goods as having symbolic significance" (Levy, 1959, p. 117).

We can call it an indicator of something deeper, meaningful, sacral, negative and positive at the same time. One of the reasons which increase the conflicts related to symbolism is that we confuse the language (meaning and our understanding of it) used in different disciplines such as sociology, philosophy, theology and in marketing as well in this article we cannot exclude this interdisciplinary approach. Advertising with symbolic meaning has been evaluated from various views in order to understand this construct: the meaning of products in society as well as consumers' identity were identified by R. W. Belk (1995), M. Csikszentmihalyi and E. Rochberg- Halton (1981); G. Ger and R. W. Belk (1996), C. W. Park et al. (2010), S. Lee et al. (2014), X. Sun et al. (2014).

Mainly the majority of studies focus on the symbolic contact, specifically, symbolic consumption (Belk, 1995; Ger, 
Belk, 1996). Additionally, necessary to add that in the marketing literature companies emphasise not only the demand to please customers' desires by offering quality products and good services, however currently consumers demand emotions or memorable experiences (Pine \& Gilmore, 1998).

Religion is important and enduring power in culture (Mathras et al., 2016), more than $80 \%$ of world population consider themselves religious (Pew Forum, 2017). Religion is able to effect a diversity of consumer behaviours (Mathras et al., 2016), including maintainable consumption (Minton, Kahle, and Kim, 2015), brand attitude (Rindfleisch, Wong, and Burroughs, 2010), spirituality in business (Lee, Lovelace, and Manz 2014), marketplace acknowledgments (Minton, 2016), as well as consumer's life in general.

Recent research in marketing shows that religious consumers of advertising more trusting than less or non-religious consumers (Minton 2015). Religion has always depended upon the availability of shared symbols, practices and languages. Subsequently, most of religious values and allusions have been seen assimilated into advertising strategies (Minton, 2015). We assume religion as connection to the beliefs and values that lead to purpose of life, frequently rooted in credence to God or other spiritual creature.

The connection between branding and religion origins in consumer value is varied. Some studies states that this connection lies in the roots of religions are brands depending on how it is promoted (Einstein, 2008; Alserhan, 2010). Some researches advise that brands and religion are replacement for one another, both giving to people a feeling of confidence
(Shachar et al., 2011). However, some of consumers perceive religion as a value concept that can be conversed by brands (Taylor et al., 2010, Minton, 2016). Furthermore, symbolism is one of the most important matters for both sides (some state even an essence) in religion and even more, in all understanding of it. It is widely believed that symbols help to explain the aim of religion. In telling a narrative, it builds connection with believer. This perception is found especially in Christianity (not denying other religions). As T. L. K. Dupré (2000) states: "In religion as in aesthetics, only the symbolization gives its specific character to the experience. There is no religious experience prior to the religious symbolization. Faith is never an immediate feeling or emotion" (Dupré, 2000, p. 20). The religious symbols, like other kinds of symbols, open up a level of reality which is more hidden than open. P. Tillich and R. C. Kimball clarifies (2009): "There is the fundamental level, the level below all other levels, the level of being itself, or the ultimate power of being" (Tilich, Kimball, 2009, p. 17).

Most of marketers agree that Christian messages and symbols have solid connotation inside a religious context, but do these meanings transfer in market exchanges? Do these religious symbols have any optimistic consequences on consumers? Since there is not enough research studied consumer responses to Christian religious symbols in the marketplace, nevertheless, the possible value is still not really clear. Although studies in the secular marketplace of religious symbols has been studied before (e.g., Belk, 1989), the detailed influence of religious symbols (Christian) in advertising on consumer responses to purchasers has 
not been addressed. Religious symbols are symbols of the holy and the reality is holiness, even though the participation is not their identity. Everything that belongs to time and space has become, at the same time in the history of religion, a symbol of the holy and this encounter rests on the ultimate ground of our existence (relationship between humans and the cosmos). Religious symbols stand symbolically and participate in a position they refer to, which they are supposed to replace and ultimately become. Consequently, in those moments when they start standing in that position, they become idols. P. Tillich and R. C. Kimball's (2009) understanding of this: "All idolatry is nothing else than the absolutizing of symbols of the Holy, and making them identical with the Holy itself. It is always dangerous that a holy person becomes a God or paraphrasing for our topic, a celebrity who symbolizes an ideal human being becomes an ideal or idol in the consumer's world" (Tilich, Kimball, 2009, p. 15). The religious symbol remains beyond our reach and the symbolizing act itself accentuates the discrepancy between presentation and content. As T. L. K. Dupré (2000) noted, religious symbols present their origin in such a manner that they not only signify more than they represent but also fail to disclose the nature of what they signify. Shortly, they are more hiding than disclosing.

Genuine religious symbols are ontological in nature, and they are (like that) prior to any rational reflection. Indeed, what we now call "religious" symbols grew out of our ancestors' first attempt to articulate reality. Originally all symbols were part of the same sphere of existence (Dupré, 2000). Symbols reunite the world after they have first separated it into distinct levels. Lately, psychology and sociology have given a great deal of attention to the unique power of symbols to integrate values and realities into existential units (Tillich, Kimball, 2009). At this moment, symbols are used in order to pursue goods and they send hidden messages to the consumers in order to seduce with values or ideas companies are representing. Looking into the symbol, which can be used in advertising or branding, we have to ask ourselves: "What stands behind colours, a frame or a way of performance?" We have to look into this creative work in the same way as we do with artwork. Then we can distinguish between commercial desires and public temptations. Consumer goods are carriers of a meaning, for example they are the signs of belonging to a power of social class. Mostly everything depends on what label/brand one is wearing, and it already shows how much he (she) earns. Religious symbols in branding show what values a person is seeking in one's life and to which category of people we attribute ourselves to belong (Halstead, Haynes, and Taylor, 2009).

Advertisers want to amaze their audiences by choosing symbols out of their pleasure in a situation where a bit of shock value appears (Dahl, Frankenberger, Manchanda (2003)); some supportive ideas to define this fact: (1) shock always gets full attention; (2) it is better than other types of requests in that regard contrary to expectation, (3) people memorize the data in the advertising as well as involved in message-relevant attitude (Dahl, Frankenberger, Manchanda 2003). Religious symbols are one of the shocking methods, which work always. Religion is still considered taboo as well 
as religious symbols, imageries, icons (e.g., in Lithuania for offensive advertising marketers get fine). The supporting part of shock in communication, as N. L. Pope et al. (2004) define, "it is strongly dependent upon transgression of a social or cultural taboo with provocation more likely to occur when a substantial portion of the audience is shocked by what they have seen" (Pope, Voges, Brown, 2004).

Christian symbolism is so powerful that most people recognize whether they belong to the Church or not. Advertising can make use of the characters of Jesus, Mary, St. Peter or more widely known religious symbols as, for instance, heaven, hell, eternal life, sin and typical ones such as a cross, angels, innocent babes. As many of us already recognize, companies who use religious symbols in their commercials try to add a specific message with an extra meaning or association. For example, an apple is no longer just an apple, whereas it is a piece of fruit used for temptation in paradise. This kind of language used in commercials, which uses religious language or symbolic meanings, tries to make a 'divine' offer which would be hard to refuse (Lee, Lovelace, Manz, 2014). It is being arguing for a while that, today's, advertising companies desire for an extra spiritual value is in itself a sign that religious needs are as urgent today in the socalled secular society as they have always been, even if they are no longer satisfied by traditional religions or in traditional ways (Lee, Lovelace, Manz, 2014) People buy not just a product but what is behind it, and symbols make it even more real and mark it as a part of the consumption tribe.

Of course, the understanding of the symbols in advertising depends on the background of the viewers, as we have already mentioned. In the western world, most people are familiar with them. In the eastern part of the world, advertisers have to refer to other images, values and the symbols which represent them (Sheffield, 2006). Furthermore, video advertising as well as other traditional media more and more frequently portray individualized and privatized religion. You could look at any product at all, it would seem from ordinary bread to a holiday cruise, can be advertised through an appeal to religious practices like prayer or meditation.

As we observed before, "brands used as symbols can act as efficient communication devices, which enable people to convey messages about themselves and to facilitate expressive gestures" (Sheffield, 2006 , p. 159), such as what kind of credit card you are using and what kind of brand of lipstick one puts on your friends or people you would like to impress.

It is generally agreed that, while we may think that advertising is "just selling a product", it sells the oppression of consumption (Twitchell, 2000). The weak and marginalized have been tripped into a commodifying system, a "false consciousness" and a "fetishism" that only we, the unlighted can correct by using icons, which we fall as devout market believers and, unnoticed, consumers sometimes become the seekers of false marketer's idols.

\section{Branding as fetishism}

Scientific research shows that the development of dominant and flourishing industry with strong brands can be understood as commodity fetishism in a Marxist way and supports inclusion of 
fetish products into consumption culture. Advertising and the commodity have become powerful, basically, because people started to trust things more than people. From this perspective, we do not need to search for the reason as to how we established this whole economic system which we are living in now. Our present culture values become, to some extent, part of the "fetis", we have "fetished" ourselves. To elaborate on this idea, commodity fetishism belongs to a part of studies in popular culture together with advertising and consumerism. We cannot imagine ourselves without any symbolical meaning by which we put emphasis on our personalities or on social relationships.

The first-place commodities demonstrate the hidden cultural connections with things, objects through individual work, to make them accessible through social relations and in that way to become meaningful. The role of advertising is to hide ourselves in an imaginary world. What researches see are massive creations of goods skilled of pleasing and imitating various symbolic methods and they look wholly at consumption to describe this diversity, forgetting the deeper reality of commodity production. In separating commodities from their material basis in commodity itself, they flow of into the perfect "ionosphere" of the "code" or "culture" (Leis, Kline, Jhally, 1990).

To some extent, a fetish becomes 'a body' or a certain object with one's consciousness and will, and of course with one's intentions to it. According to M. Godelier (1973), who looks at the fetish from a psychoanalytical point of view: "The fetish is a pathological instance of object - cathexis, or to speak in the Marxist vein of the fetish, as a chimeri- cal conclusion of a thought process that habitually anthropomorphizes the natural world." (Godelier, 1973, p. 58). It is widely believed that the term 'fetishism' is only related to primitive (or even belongs to savage) cultures and their methods to practice, especially for worshipping 'false idols, or the myth of the "Golden calf" From this particular perspective, then, we want to describe 'fetish'. It is useful to take into account, what is a thing (commodity) and what it is not. Only then can we explain and explore from our experience what it is to change objects into subjects (and vice-versa).

In the symbolic scheme of contemporary capitalist society, which is amused by advertising, the purchase is a fetish. This fetish object dismisses meaning and flexible value, the fetish characterises an unbalanced heart of a shifting collection of religious symbols, values for specific religion (in this case, Christianity) in which this, consequently, always threated to be revealed as rather made with a fake focus on religious craving (Campbell, La Pastina, 2010). Many Apple fans experience the bond with their computers as personal and sacred-they are emotionally attached to their computer and think of it as a friend (Pogačnik, Črnič, 2014). Through interacting with Apple products, buying accessories for them, or just reading about Apple, they enter into "the Apple world," where special rules and beliefs apply, which enable them to escape from the everyday life (Jindra, 2000, p. 173). Apple users rarely throw away Apple devices they own, and they often reuse these religious fetishes-sometimes as aquariums or Macquariums or for building their own museums of Apple computers (e.g., Digibarn). In addition, some fans collect 
Apple's promotional merchandise (posters, watches, t-shirts, etc.) and design desirable future products, and those who cannot afford Apple products build them out of paper (Pogačnik, Črnič, 2014). An interesting example of religious symbolism connected with Apple's iPhone is its nickname: "Jesus phone" (Campbell, La Pastina, 2010). Naming a device "Jesus phone" denotes "the gadget being divine or at least the choice of the divine" (Campbell, 2010), sent by God to the Earth via Steve Jobs.

Another example of fetish and the work of a symbol is Coca-Cola's chalice. Of all liturgical objects, the chalice is the most high-profile and one of the most important recipients in all of western culture. It is not just a magical container itself, but it holds the central magic of the entire religion. We all heard that it started with a secret formula which was tinctured with cocaine and until now the company has not revealed this recipe. The iconography of Coca-Cola and the name is the most recognizable in the world. Consequently, it can simply be interpreted as: "this cup is my blood... which is shed for many" (Mt 26:28; Mk 14:24; Lk 22:20). This metaphor from the last supper of Jesus Christ is the blood which the chalice lacks so that the receptacle becomes an equivalent of the sacrificial blood (Sheffield, 2006). CocaCola and its entire company (including Schweppes, Sprite, Fanta) undoubtedly is the most known soft drink in the worldCoca-Cola is not just the bestselling also the world's best-known brand name established over the hundred years. CocaCola presumes that the only real competitor for them is water. The company has $50 \%$ share the world market for carbonated drinks and the main Coca- Cola's competitor actually is Pepsi Cola, which has $20 \%$ of the world market (Chidester, 2015). At the same time, it is the most controversial and, we even dare say, the most successfully advertised product in the world. Coca-Cola is a religion because it is: "A system of symbols which acts to establish powerful, pervasive and longlasting moods and motivations in men by formulating concepts of a general order of existence and clothing these terms in such an aura of factuality that the moods and motivations seemed uniquely realistic" (Pendergrast, 1997). Delony Sladge, an advertising director of Coca-Cola in the early 1990s, proclaimed: "Our work is a religion rather than a business". Apparently, the Coca-Cola company has created its company as a religious message (Chidester, 2015). The Coca-Cola company also presumed that religious meaning for the buyer owning "centred the lives of people", as one of the managers said, "more than any other product or ideology, including the Christian religion" (Pendergrast, 1997). Although the religious importance of Coca-Cola is widely known, in 1931 it gave the US and the entire western world its standard image of Santa Claus by introducing cheerful old personality with overweight and white beard, robed in Coca-Cola red. Moreover, it developed into the most significant icon of the lifestyle besides for US soldiers during the Second World War, as it was presented as an unusual holy moment - "the pause that refreshes", redeeming them from usual post-war daily life. As for more, from the 1960's on, it guaranteed to give a better world "in perfect harmony". The company had the idea to introduce a new type of Coca-Cola in 1985 which caused one executive to exclaim, "They 
talk as if Coca-Cola had just killed God" (Levin, 1981).

A sceptical question could be raised at this point: how can it be that we are talking about a refreshing drink in the same manner as about religion (even putting it in the same context), which maybe was just prosperously sold with the help of advertising? The surprise here could be that the Coca-Cola company created a product which nobody actually needs. Therefore, the doubter would finish that it is just a wise way of manipulation toward a "desire thought" by effective advertisers and that it has nothing to do with religion.

As J. Baudrillard (2001) emphasizes the use of value by a fetishized social relation through the manipulation of the symbolic code, any object can take on any symbolic meaning regardless of its physical constitution. For instance, a car may be elegant, sophisticated, exciting, youthful, manly, feminine etc. There is nothing appropriate in an object as such to give it an intrinsic meaning and depending on its place in a sign system it can take any one of these meanings. For J. Baudrillard (2001) use-value itself is a form of equivalence and as such capable of being manipulated within a system of exchange.

Mostly, Coca-Cola is not just an example of fetish and symbol effectiveness in society. It is a strong brand as well, which describes more than just a sort of drink you choose to refresh yourself. Therefore, we may continue this line of thought: you are what you wear, what you drive, where you go on holiday, where you live and even what you decide to watch on video. "Tell me what you buy, and I will tell you who you are and who you want to be" (Twitchell, 2000). The question rises as to how, from buyers of simple products, we end up being the seekers of new religion?

\section{Brand religion}

Brands are established as cultural codes in the consumer society (Batra et al., 2012; Albert, Merunka, 2013; Bagozzi, Batra, Ahuvia, 2017). Emotional attachment to brands becomes also feelings (Thomson, MacInnis, Park, 2005). There are many terms to describe the phenomenon of brand, defining as "the sum total of all define love for a brand as "a combination of emotion utilities, benefits, values, personality traits, images, impressions, associations and experiences a consumer perceives around a product or service" (Tiwari \& Rajendra, p. 62, 2012). Scholars approve that this affection mood occurs with the purchaser and consumer (Carroll, Ahuvia, 2006; Shimp, Madden, 1988). Nowadays, scientists reflect love for brand as a new thing in market (Albert, Merunka, 2013; Carroll, Ahuvia, 2006; Kamat, Parulekar, 2007). Carroll and Ahuvia (2006), goes deeper and studies even the feeling of passion. With the latter idea agrees companies, which have been successful in building the strong brands "that transcend their physical existence, take on a life and build meaningful relationship with the consumers" (Tiwari, Rajendra, 2012, p. 63). Brands create structure of religion with declared love and creates even brand cults such as Harly Davidson, Apple, etc. Steve Jacobs took an idea as a leader very close to the Jesus in the process of developing Apple brand like Christianity and according to A. Pogačnik and A. Crnič (2014) the Apple brand keeps they symbol as sacred of the community, 
saved by the taboo of criticism. The products behave as religious objects to Apple devotees, and Apple shops function as temples. Followers complete public pilgrimages to shop openings, also private rituals of product unboxing (Pogačnik, Črnič, 2014). Brands as such share the common elements which usually religion has: clear vision; a sense of belonging; an enemy; sensory appeal; storytelling; grandeur; evangelism; symbols (Campbell's, 2010; Pogačnik, Črnič, 2014). Furthermore, branding can be comparable to religion where people begin to get confused about the use of symbols. Advertising companies and brand creatures call it "the act of peace", to alleviate some problems. It can remove stigma, sin, guilt, redemption from sorrow, provides resolution and angst (Stolz, Usunier, 2018).

C. S. Carver et al. (2000) studied the types of brands, the foundation was made that from ordinary brands after some time brands created their own meaning. Even if advertising uses cliché phrases or jingles the real meaning comes after years, collected of communication and goods in byer's memory, and clarify essence. The goal of design is to achieve its symbolic value. According to N. Klein (2000), branding is about a global lexicon of imagery, music, icons", and in this fashion, it transfuses a code into our brains.

Branding, as a new member of the community (even leadership with companies such as Nike, Benetton, and Starbuck's which have built their brands on meanings such as transcendence, multiculturalism and belonging, respectively, puts spirituality into the market), offers a permanent, bounded identity, in which you are told about your real self. It suggests an invitation to endless confidence.
It promises a new life (Beaudoin, 2007). It can even be seen as taken from western spiritual disciplines. It proves that "economy as a discipline is not consciously 'spiritual' or 'religious', but it operates with a dynamic similar to classical spiritual disciplines - anonymously". We will see how companies do this deliberately.

Brand is not just a name of a company or a product. It contains even more: a myth, a symbol which serves emotional meaning. It is influenced by many aspects, on the one hand, in the case of creating and formulating a brand. Companies ask themselves many questions such as: what is the historical background of the company and country in which they wish to launch a product. Does it have any national or regional thought? What gender is this brand: male or female? Does its packaging or presentation format fit with a contrast against the 'norms' in its market? What kind of message, symbol or value does the brand want to spread among the consumers? Brands with stability in their promises, images, identity, quality and advertising are basically the strongest in their class. When a strong brand can change, is able to keep pace and develop, generating awareness, will it be able to create brand preference? As we mentioned before, brands have to adjust themselves to individual responses to satisfy one's needs (Beaudoin, 2007).

It is already a part of history: when marketing experts discuss about brands, they have in mind the product itself with its quality, its price and, of course, its function. These days, it's not enough to sell a product or a service. Moreover, it's supposed to place something beyond or behind it. Otherwise, nobody will pay attention to it. No need to think too much. 
You just need to look at what surrounds you, which kind of advertising, promotions you can see around your home, university or workplace? Is it brightly red Coca-Cola, a McDonald's cheeseburger or maybe a cup of Starbuck's coffee? The question arises: what kind of lifestyles are we admiring behind or beyond our surrounded brands which reflect our daily life and our personalities, what kind of values and dreams are they establishing in us?

These days, the branding culture has become the same as religion and could be described as Marx (1975) state with his famous quotation, as opium for the people. It becomes: "a form of alienation; it is a symptom of social malformation which distinguishes the exploitative relationships of capitalist society" (Davie, 2007; Tan and Vogel, 2008; Berggren, Bjørnskov, 2011). Many pessimistic scholars mention religion as a tool to persuade (Gineikiene,, Zimaitis, Urbonavičius, 2015; Putrevu, Swimberghek, 2013; Rehman, Shahbaz Shabbir, 2010.) and affirm the dominant worldview, thou brands supposed to work as a product in which consumer could trust. More specifically, trust in marketing can be or to brand itself or in the marketplace. They say that the market as the new religious groups bring critical but dominant members of society not just with a new name, but with new inspirations.

Brand in a context of religion is usually taken as a negative meaning, but it can have a positive view in the way to explain Jesus as a kind of brand. Firstly, as a name of the product (brand), Jesus has a corporate identity. It is not about the Jesus brand as "spirituality", as a generic one, which can arise the support of any numbers of outcomes. It is about shap- ing certain kinds of deeds, establishing a particular kind of worldview. Secondly, this term "brand" also implies that this is a spiritual message over which Jesus demonstrates proprietary rights (Wilson, 2008). These days, of course, it is no surprise that Jesus is used as a brand. Not long ago the boycott was lifted for the name like that of jeans.

The branding approach is based on creating a unique and symbolic psychological association and identification between the brand and the consumer. Here, the brand differentiation comes from the brand trying to occupy the unique 'personality' and 'lifestyle' imagery and associations that their target audiences identify with and aspire for. Scholars claim that the nature of branding is to be a promise in the mind of the consumer (Pringle and Thompson, 1999). Brand "identity" elements (the promise) usually attack every one of us and that's the reason why we buy one product instead of another.

Therefore, it is still gratifying to know and, even more, to admit that in this consumerist and world there is still the place for creed and spirituality. On the other hand, it is a deplorable fact that religion and in this particular context, symbols, values, ideas of Christianity to some extent, has been used in order to increase value of the brand and a company itself.

\section{Conclusions}

In conclusion, everybody has his/her belief in the system which can be ingrained in religion (here we are approaching Christianity, Buddhism, Hinduism, or Islam) as well non-religious (Agnosticism, Atheism, naturalism, humanism) causes. 
Therefore, all these systems bring to the need to pursue some kind of spirituality, even if it comes through consuming goods. Marketers see this never-ending necessity to fill our inner selves as a gap for their super products. They use brands to demonstrate that not only our identities fulfilled as possible but also the product (service) with specific quality mark. It is also a part of the cultural values despite the geographical location or historical heritage (in Lithuania the consumerism phenomenon came later due to the Soviet occupation). Some conclusions could be made from our analysis:

- The cultural dimension (such as rational values) plays an important role from the consumer's point of view here converts into religious symbols. This dimension helps advertisements to use the circumstances in which these symbolic goods act in the marketplace. For the future research, it would be useful to pay more attention to Christian symbolism and their effect to costumers.

- Advertisers want to amaze their audiences by choosing symbols as shocking advertising. Religious symbols are one of the shocking methods which always get attention. At the same time, it is not just shocking, it demonstrates the need of being seduced by symbols or by the need to act morally right by choosing specific symbol or the value product advertise.

- Culture gives space to the use of value with a help of fetishized social relationship and through the manipulation of the symbolic code with specific meaning and effect.

- The branding approach is based on creating a unique and symbolic psychological association and identification between the brand and the consumer. Here, we find that the brand differentiation comes from the brand trying to occupy a unique "personality" and "lifestyle" imagery and associations that their target audiences identify with and aspire for. As we noticed, the essence of branding is to be a promise for a consumer which helps to decide what to purchase.

To sum up, since the global processes erase cultural differences in the future research, we will seek to assess interconnections between cultural environment and different religions plus their effect to consumer satisfaction.

\section{References}

1. Albert, N., Merunka, D. (2013). The Role of Brand Love in Consumer-Brand Relationships // Journal of Consumer Marketing. No. 30(3), pp. 258-266. doi: 10.1108/07363761311328928

2. Bagozzi, R. P., Batra, R., Ahuvia, A. (2017). Brand Love: Development and Validation of a Practical Scale // Marketing Letters. Vol. 28(1), pp. 1-14. doi: 10.1007/s11002-016-9406-1

3. Batra, R., Ahuvia, A., Bagozzi, R. P. (2012). Brand Love // Journal of Marketing. Vol. 76(2), pp. 1-16. doi: 10.1509/jm.09.0339.
4. Baudrillard, J. (2001). Consumer Society: Myths and Structures. - London: SAGE Publications Ltd.

5. Beaudoin, T. (2007). Consuming FaithIntegrating Who We Are with What We Buy. -Rowman \& Littlefield.

6. Belk, R. W. (1995) Collecting in a Consumer Society. - London: Routledge.

7. Berggren, N., Bjørnskov, C. (2011). Is the Importance of Religion in Daily Life Related to Social Trust? Cross-Country and Cross-State 
Comparisons // Journal of Economic Behavior and Organization. Vol. 80(3), pp. 459-480. doi: 10.1016/j.jebo.2011.05.002

8. Campbell, H. (2007). What Hath God Wrought: Considering How Religious Communities Culture (Or Kosher) The Cell Phone. Continuum // Journal of Media and Cultural Studies. Vol. 21(2), pp. 191-203. doi: 10.1080/10304310701269040.

9. Campbell, H. A., La Pastina, C. A. (2010). How the iPhone Became Divine: New Media, Religion and the Intertextual Circulation of Meaning // New Media \& Society. Vol. 12(7), pp. 1191-1207. doi:10.1177/1461444810362204.

10. Carroll, B. A., Ahuvia, A. C. (2006). Some Antecedents and Outcomes of Brand Love // Marketing Letters. Vol. 17(2), pp. 79-89.

11. Carver, C. S., Sutton, S. K., Scheier, M. F. (2000). Action, Emotion, And Personality: Emerging Conceptual Integration // Personality and Social Psychology Bulletin. Vol. 26(6), pp. 741-751. doi: $10.1177 / 0146167200268008$.

12. Chatzidakis, A., Lee, M. (2013). AntiConsumption as the Study of Reasons Against // Journal of Macromarketing. Vol. 33(3), pp. 189-204. doi: 10.1177/0276146712462892.

13. Chidester, D. (2015). The Church of Basketball, the Fetish of Coca-Cola and the Potlatch of Rock n' Roll / In Bruce David Forbes, Jeffrey H. Mahan ed., Religion and Popular Culture in America. - Berkeley: University of California Press.

14. Csikszentmihalyi, M., Rochberg-Halton, E. (1981). The Meaning of Things: Domestic Symbols and the Self. - Cambridge: Cambridge University Press.

15. Dahl, D. W., Frankenberger, K. D., Manchanda, R. V. (2003). Does It Pay to Shock? Reactions to Shocking and Nonshocking Advertising Content among University Students // Journal of Advertising Research. Vol. 43, Issue 3, pp. 268-280. doi: 10.1017/S0021849903030332

16. Davie, G. (2007). The Sociology of Religion. Los Angeles, CA: Sage.

17. DeChernatony,L.,McDonald,M.(2013).Creating Powerful Brands. - Butterworth-Heinemann.

18. de Maeseneer, Y. (2003). I had Barbie in My Brain / In Desirable God: Our Fascination with Images, Idols and New Deities, eds. Roger Burggraeve, Johan De Tavernier, Didier Pollefeyt, Jo Hanssens. - Leuven: Peeters, pp. 241-265.
19. Diego, R., Scott, L., Maclaran, P. (2013). Consumption and Spirituality. - New York: Routledge, pp. 16-25.

20. Dupré, T. L. K (2000). Symbols of the Sacred. Grand Rapids, MI: Eerdmans, pp. 114-126.

21. Edson, J. E., Bettman, J. R. (2005). SelfConstrual, Reference Groups, and Brand Meaning // Journal of Consumer Research. Vol. 32(3), pp. 378-389. doi: 10.1.1.108.5210.

22. Einstein, M. (2008). Brands of Faith: Marketing Religion in a Secular Age. - Routledge, London, UK, pp. 136-148.

23. Ekins, P; (1991). A Sustainable Consumer Society: a Contradiction in Terms? // International Environmental Affairs. Vol. 3(4), pp. 243-258.

24. Flügel, J. C. (1930). The Psychology of Clothes. - London: London Press.

25. Featherstone, M. (1991). Consumer Culture and Postmodernism. - London: Sage, pp. 5-9.

26. Ger, G., Belk, R. W. (1996). Cross-Cultural Differences in Materialism // Journal of Economic Psychology. Vol. 17, pp. 55-77. doi:10.1016/0167-4870(95)00035-6.

27. Gineikienè, J., Zimaitis, I., Urbonavičius, S. (2015). Controversial Use of Religious Symbols in Advertising / In Ideas in Marketing: Finding the New and Polishing the Old. - Springer International Publishing, pp. 47-50.

28. Godelier, M., 1973 . The Concept of Tribe: Crisis of a Concept or Crisis of the Empirical Foundations of Anthropology? // Diogenes. Vol. 21(81), pp. 1-25. doi : 10.1177/039219217302108101.

29. Gottdiener, M. (1985). Hegemony and Mass Culture: A Semiotic Approach // American Journal of Sociology. Vol. 90, No. 5, pp. 979-1001.

30. Grayson, K., Radan, M. (2004). Consumer Perceptions of Iconicity and Indexicality and Their Influence on Assessments of Authentic Market Offerings' // Journal of Consumer Research, Vol. 31 (September), pp. 296-312. doi: 10.1086/422109.

31. Halstead, D., Haynes, P. J., Taylor, V. A. (2009). Service Provider Use of Christian Religious Messages in Yellow Pages Advertising // Advertising \& Society Review. Vol. 10(4). doi: 10.1353/asr.0.0038

32. Hamish, P., Thompson, M. (1999). Brand Spirit: How Cause Related Marketing Builds Brands. Chichester: Wiley, pp. 223-228. 
33. Hassan, S. S., Katsanis. L. (1994). Global Market Segmentation Strategies and Trends / In Salah S. Hassan and Erdener Kaynak (eds), Globalization of Consumer Markets: Structures and Strategies. - New York: International Business Press, pp. 47-62.

34. Hofstede, G., Hofstede, G. J., Minkov, M. (2010). Cultures and Organizations: Software of the Mind, 3rd ed. - New York: McGraw-Hill.

35. Holt, D. B. (2002). Why Do Brands Cause Trouble? A Dialectical Theory of Consumer Culture and Branding // Journal of Consumer Research. Vol. 29 (June), pp. 70-90. doi: $10.1086 / 339922$

36. James, W. (1890). Principles of Psychology. New York: Holt.

37. Inglehart, R., Baker, W. E. (2000). Modernization, Cultural Change, and the Persistence of Traditional Values // American Sociological Review. Vol. 65(1), pp. 19-51. doi: $10.2307 / 2657288$.

38. Inglehart, R., Welzel, C. (2005). Modernization, Cultural Change, and Democracy: The Human Development Sequence. - Cambridge: Cambridge University Press, pp. 61-79.

39. Kamat, V., Parulekar, A. A. (2007). Brand LoveThe Precursor to Loyalty / In Joseph R. Priester, Deborah J. MacInnis, \& C. Whan Park (Eds) // Advertising and Consumer Psychology: New Frontiers in Branding; Attitudes, Attachments, Relationships. - Santa Monica, CA: Society for Consumer Psychology, pp. 94-98.

40. Klaus, P., Maklan, S. (2013). Towards a Better Measure of Customer Experience // International Journal of Market Research. Vol. 55, No. 2, pp. 227-246. doi: 10.2501/ IJMR-2013- 021.

41. Klein, N. (2010). No Logo: Taking Aim at the Brand Bullies. - Vintage: Picado, pp. 69-84.

42. Koziniets, R. V. (2002). Can Consumers Escape the Market? Emancipatory Illuminations from Burning Man // Journal of Consumer Research. Vol. 29, pp. 20-38. doi: 10.1086/339919.

43. Lee, S., Lovelace, K. J., Manz, C. C. (2014). Serving with Spirit: An Integrative Model of Workplace Spirituality within Service Organizations // Journal of Management, Spirituality \& Religion. Vol. 11, No. 1, pp. 45-64. doi: 10.1080/14766086.2013.801023.

44. Leiss, W. S., Kline, S., Jhally, S. (1990). Social Communication in Advertising-Persons, Products and Images of Well-Being. Routledge, pp. 8-19.
45. Levy, S. J. (1959). Symbols for Sale // Harvard Business Review. No. 37, pp. 117-124.

46. Lury, C. (2011). Consumer Culture. - New Brunswick, NJ, pp. 56-68.

47. Mathras, D., Cohen, A. B., Mandel, N., Mick, D. G. (2016). The Effects of Religion on Consumer Behavior: A Conceptual Framework and Research Agenda // Journal of Consumers Psychology. Vol. 26, No. 2, pp. 298-311. doi: https://doi.org/10.1016/j.jcps.2015.08.001.

48. McSweeney, B. (2002). Hofstede's Model of National Cultural Differences and Their Consequences: A Triumph of Faith-a Failure of Analysis // Human Relations. Vol. 55(1), pp. 89-118. doi: 10.1177/0018726702551004.

49. Miller, D. (1987). Material Culture and Mass Consumption. - Oxford: Blackwell, pp. 230-235.

50. Minton, E. A. (2015). In Advertising We Trust: Religiosity's Influence on Marketplace and Relational Trust // Journal of Advertising. Vol. 44(4), pp. 403-414.

51. Minton, E. A. (2016). Sacred Attributions: Implications for Marketplace Behavior // Psychology \& Marketing. Vol. 33(6), pp. 437448. doi: 1002/mar.20889.

52. Minton, E. A., Kahle, L. R. (2017). Religion and Consumer Behaviour / In: Jansson-Boyd, C. V., Zawisza, M. J. (Eds.), International Handbook of Consumer Psychology. - Routledge, New York, NY, pp. 292-311.

53. Minton, E. A., Kahle, L. R., Kim, C. H. (2015). Religion and Motives for Sustainable Behaviors: A Cross-Cultural Comparison and Contrast // Journal of Business Research. Vol. 68(9), pp. 1937-1944. doi: 10.1016/j. jbusres.2015.01.003.

54. Park, C. W., Deborah, J. M., Priester, J., Eisingerich, A., Iacobucci, D. (2010). Brand Attachment and Brand Attitude Strength: Conceptual and Empirical Differentiation of Two Critical Brand Equity Drivers // Journal of Marketing. Vol. 74, No. 6, pp. 1-17. doi: http:// dx.doi.org/10.1509/jmkg.74.6.1.

55. Pendergrast, M. (1997). For God, Country and Coca-Cola - the Unauthorized History of the Great American Soft Drink and the Company That Makes it. - Simon \& Schuster.

56. Pew Forum (2017). The Landscape Global Religious. Internet access: http://www. pewforum.org/2017/12/18/global-religiouslandscape-exec/. >, [accessed May 9, 2019]. 
57. Pine, J. B., Gilmore, J. H. (1998). Welcome to the Experience Economy // Harvard Business Review. Vol. 3, pp. 97-109.

58. Pogačnik A., Črnič A. (2014). iReligion: Religious Elements of the Apple Phenomenon // Journal of Religion and Popular Culture. Vol. 26, No, 3, pp. 356-364. doi: 10.3138/jrpc.26.3.353.

59. Pope, N. L., Voges, K. E., Brown, M. R. (2004). The Effect of Provocation in the Form of Mild Erotica on Attitude to the Ad and Corporate Image: Difference between Cause-Related and Product-Based Advertising // Journal of Advertising. Vo. 33, No. 1, pp. 69-82.

60. Putrevu, S., Swimberghek, K. (2013). The Influence of Religiosity on Consumer Ethical Judgments and Responses toward Sexual Appeals // Journal of Business Ethics. Vol. 115, No. 2, pp. 351-365. doi:10.1007/ s10551-012-1399-y.

61. Rehman, A., Shahbaz Shabbir, M. (2010). The Relationship between Religiosity and New Product Adoption // Journal of Islamic Marketing. No. 1, pp. 63-69. doi: doi:10.1108/17590831011026231.

62. Rindfleisch, A., Wong, N., Burroughs, J. E. (2010). God \& Mammon: The Influence of Religiosity on Brand Connections / In The Connected Customer: The Changing Nature of Consumer and Business Markets, edited by Wuyts, S. H. K., Dekimpe, M. G., Gijsbrecths, E. \& Pieters, R. - Mahwah, NJ: Lawrence-Erlbaum, pp. 163-202.

63. Shachar, R., Erdem, T., Cutright, T. M. (2011). Brands: The Opiate of the Nonreligious Masses? // Journal of Marketing Science. Vol. 30, No. 1, pp. 92-110. doi: 10.1287/mksc.1100.0591

64. Sheffield, T. (2006). The Religious Dimensions of Advertising. - Palgrave Macmillan, pp. 98-100.

65. Slater, D. (1997). Consumer Culture and Modernity. - Cambridge, UK: Polity, pp. 56.
66. Solomon, M. R (1992). Consumer Behavior. Boston: Allyn \& Bacon.

67. Stolz, J., Usunier, J. C. (2018). Religions as Brands? Religion and Spirituality in Consumer Society // Journal of Management, Spirituality \& Religion. Vol. 16, No. 1, pp. 6-31. doi: 10.1080/14766086.2018.1445008.

68. Simmel, G. (1903). Fashion. - Los Angeles: University of California Press.

69. Sun, X., Wang, P., Lepp, A., Robertson, L. (2014). Symbolic Consumption and Brand Choice: China's Youth Hostels for the International Travel Market // Journal of China Tourism Research. No.1, pp. 51-68. doi: 10.1080/ 19388160.2013.870950.

70. Thomson, M., MacInnis, D. J., Park, C. W. (2005). The Ties that Bind: Measuring the Strength of Consumers' Emotional Attachments to Brands // Journal of Consumer Psychology. Vol. 15, No. 1, pp. 77-91. doi: 10.1207/ s15327663jcp1501_10.

71. Tilich, P., Kimball, R. C. (2015). The Nature of Religious Language in Theology of Culture. Oxford University Press, pp. 15-18.

72. Tiwari, K., Rajendra, S. (2012) Perceived Impact of Ingredient Branding on Host Brand Equity // Journal of Marketing and Management. Vol. 3, No. 1, pp. 60-77. doi: 10.1509/jmkg.66.1.73.18450.

73. Triandis, H. C. (2018). Individualism \& Collectivism. - New York, NY: Routledge, pp. 139-145.

74. Twitchell, J. B. (1999). Lead us into Temptation. New York (N.Y.): Chichester, West Sussex.

75. Wilson, K. (2008). Jesus Brand Spirituality: He Wants His Religion Back. - Nashville, TN: Nelson, pp. 225-228.

The paper submitted: May 10, 2019 Prepared for publication: August 10, 2019 


\section{Rima ŽITKIENĖ, Gintarè KRIAUČIŪNAITĖ-LAZAUSKIENĖ RELIGINIỤ SIMBOLIỤ IR KULTŪROS VERTYBIỤ SĄVEIKA REKLAMOJE}

\section{S a n t r a k a}

Reklama yra kultūros dalis, kurioje vartotojai susikuria savo tapatybę pasitelkdami prekèse paslèptus simbolius. Remiantis G. Hofsete (2001), kultūra - tai abipusis žmonių mąstymo programavimas, pasireiškiantis ne tik vertybemis, bet ir paviršutiniškesniais būdais, tokiais kaip simbolių herojų ir ritualų paieška. Mokslinès literatūros analizè atskleide, kad yra ryšys tarp religinių simbolių ir reklaminių žinučių. Šiuolaikinèje visuomenèje ieškant sąsajų tarp kultūros ir reklamos, tikslinga naudoti R. Inglehart (2000) kultūrinès vertès metodą ir atskleisti reikšmes, kurias individai gauna iš dvasingumo „prisotintų" reklamų. Šiame straipsnyje teigiama, kad kultūros simboliai (ir jų vertybė) gali būti ịvairūs, pvz., logotipai, ịžymybès, marketingo šūkiai, socialiniai stereotipai ir t. t. Taip pat išryškinama simbolių reikšmè ir naudojimas reklamoje, nagrinejjama simbolių prasmé vartotojui renkantis prekes ir prekès ženklo svarbai.

Praktiniai tyrimai rodo, kad rinkodaros specialistai turi būti susipažinę su savo vartotojais, jų religiniais ịsitikinimais ir numatyti produktų reklamoje tokius simbolius, kurie gali paveikti jų produktų paklausą ir, taikant skirtingus rinkodaros metodus, išlaikyti nuolatinius klientus. Nors reklamoje neakcentuojama, kad laimę galima pasiekti tik pasitelkus materialius daiktus, nesakoma, jog poreikių patenkinimas skatina dorovingumą, bet pasiektas moralinis mąstymas demonstruoja pirkèjo brandos lygị, kuris būtinas kritiškai mąstančiam šiuolaikiniam pirkejjui ir tam eiliniam pirkejjui, kuris yra paveiktas simbolių tarpkultūriniame kontekste.

Nepaisant neigiamų aspektų (prekių ženklų pavertimu ikonomis, reklamos fetišizmo aukos, piktnaudžiaujant religiniais simboliais ir atvaizdais, keičiant kultūros vertybes), yra daug teigiamų aspektų, kuriuos reklama sukuria mūsų kasdienèje aplinkoje, atstovaudama prekès ženklams, o ne siekdama nuolatos gundyti mus ísigyti naujų prekių. Pvz., skatinimas įsigilinti $\mathfrak{i}$ produktų savybes ir ịsigyti ekologiškų produktų; kova už produktų kokybę ir genetiškai modifikuotų maisto produktų boikotavimas; sąžiningos prekybos skatinimas ir tvarus produktų vartoji- mas arba sveikos gyvensenos skatinimas ir požiūrių bei ịpročių keitimas; pvz., antrinis produktų panaudojimas, perdirbimas, vietinès rinkos produktu pirkimas ir pan.

Straipsnio pabaigoje apibendrinant mokslinių ir praktinių studijų rezultatus galima teigti, kad analizuojant kultūros dimensijų poveikị vartotojui, svarbus vaidmuo tenka vertybems. Todèl atkreiptinas dèmesys ị R. Inglehart (2000) išskirtą racionalią vertę, tiesiogiai susijusią su simboliais. Šiandienè reklama pasinaudoja tinkamomis aplinkybèmis, veikiančiomis ir tiesioginèje, ir virtualioje socialineje erdveje, kai simbolinès reklamos pagalba daromas poveikis vartojimui. Be to, asmeninis prieraišumas tam tikriems daiktams yra itakotas aplinkos ir veikia prekių perkamumą.

Mokslininkų D. W. Dahl, K. D. Frankenberger ir R. V. Manchando (2003) nuomone, reklamos kūrèjai nori sužaveti savo auditoriją galèdami pateikti simbolinę reklamą, kur atsiranda šoko elementas. Mokslinių darbų analizè atskleide, kad religiniai simboliai yra vienas iš šoko metodų, kuris visada sulaukia vartotojų reakcijos. Siekdami poreikių patenkinimo vartotojai priima moraliai teisingesni sprendimą ir pasiduoda reklamos simbolių vilionei, kai produktas pažymètas specifiniu simboliu ar pasižymi išskirtine verte.

Pažymètina, kad žinomus prekių ženklus vartotojai atpažįsta nepriklausomai nuo kultūros vertybių, todèl daugelis mokslininkų sutaria, kad naudodamasis fetišuotu socialiniu ryšiu ir manipuliuodamas simbolizmu bet kas gali užimti bet kokią simbolinę reikšmę ir turèti poveikị vartojimui.

Prekių išskirtinumas ir prekių ženklų kūrimas grindžiami unikalumu ir psichologiniu poveikiu vartotojui. Simboliai sukelia asociacijas ir leidžia identifikuoti prekę pagal prekès ženklą, jo žinomumą. Prekès ženklo diferenciacija susijusi su paties prekès ženklo ypatumais, kurie gali suteikti unikalumą asmenybei, jo gyvenimo būdui ar sukelti tikslinei vartotojų auditorijai asociacijų igyvendinant savo tikslus. Mokslininkai sutaria, kad prekès ženklo esmè yra pažadas vartotojui, jog jis įsigyja kokybišką ir išskirtini produktą. Visa tai susiję ne tik su poreikių patenkinimu, bet ir tiesiogiai paveikia vartotoją priimant sprendimą, ką pirkti. 